\title{
Lysozyme gene expression and hemocyte behaviour in the Mediterranean mussel, Mytilus galloprovincialis, after injection of various bacteria or temperature stresses
}

\author{
Hui Li $i^{a}$, Maria-Giovanna Parisi ${ }^{a, b}$, Mylène Toubiana ${ }^{a}$, Matteo Cammarata ${ }^{b}$ and Philippe \\ Roch $^{\mathrm{a},{ }^{*}}$
}

\author{
${ }^{a}$ Ecosystèmes Lagunaires UMR5119, Université Montpellier 2, CNRS, IFREMER, cc093, Place E. Bataillon, F- \\ 34095 Montpellier Cedex 05, France \\ ${ }^{\mathrm{b}}$ Marine Immunobiology Laboratory, University of Palermo, Via Archirafi 18, 90123 Palermo, Italy \\ *: Corresponding author : P. Roch, email address : proch@univ-montp2.fr
}

\begin{abstract}
:
The aim of the present study was to evaluate the expression of the Mytilus galloprovincialis lysozyme gene in different in vivo stress situations, including injection of bacteria Vibrio splendidus LGP32, Vibrio anguillarum or Micrococcus lysodeikticus, as well as heat shock at $30^{\circ} \mathrm{C}$ and cold stress at $5{ }^{\circ} \mathrm{C}$. Injection of $V$. splendidus LGP32 resulted in: (i) a general down-regulation of lysozyme gene expression, as quantified by Q-PCR; (ii) reduction in the number of circulating hemocytes; (iii) decrease in the percentage of circulating hemocytes expressing lysozyme mRNA which was now restricted to only small cells, as observed by ISH; and (iv) accumulation of hemocytes expressing lysozyme in the muscle sinus where injection took place. Injection of $V$. anguillarum or M. Iysodeikticus induced significant up-regulation of lysozyme gene expression, but only 2-3 days post-injection, with no change in the total hemocyte counts but an increased percentage of hemocytes expressing lysozyme mRNA. Neither the control injection of PBS-NaCl nor temperature stress modified the lysozyme expression pattern. Consequently, the hemocyte population appears to be capable of discriminating between stress factors, and even between 2 Vibrio species.
\end{abstract}

Keywords: Vibrio splendidus; Vibrio anguillarum; Micrococcus lysodeikticus; Heat shock; Lysozyme; Gene expression; Q-PCR; ISH; Mytilus; Molluscs 


\section{Introduction}

Lysozymes are small ubiquitous antibacterial enzymes that hydrolyze $\beta-1$, 4-linked glycoside bonds of peptidoglycan, a major cell wall component of Gram-positive bacteria. Several studies have shown that lysozymes are also able to kill Gram-negative bacteria, demonstrated in bivalves [1, 2] and in shrimp [3,4]. Anti-protozoan and anti-fungal activities of lysozymes, mediated by cleaving Nacetylglucosamine in chitin, have been also documented [5, 6]. In addition, lysozyme can kill bacteria by non-enzymatic activity [7]. Thus, lysozymes appear to constitute an important component of immune defence against diverse microbial infections.

Several types of lysozymes have been purified, from the best-known chicken-type (c-type) and goose-type (g-type) [8], to the more recently identified invertebrate-type (i-type) [1, 9]. Such i-type lysozyme has been identified in several bivalve molluscs, including the Icelandic scallop, Chlamys islandica [1], the blue mussel, Mytilus edulis [10], several mytilids and vesicomyids [11], and the Mediterranean mussel, Mytilus galloprovincialis, the hydrothermal-vent mussel, Bathymodiolus azoricus and the cold-seep clam, Calyptogena sp. [12]. Although numerous reports concern the different types of lysozymes and their activities [10, 12-15], only the genes from the blue mussel, $M$. edulis [12], and from the Icelandic scallop, Chlamys islandica [16], have been sequenced. Curiously, the $M$. edulis lysozyme gene comprises five exons instead of the classical four exons of the c-type lysozyme gene, such as the $C$. islandica ones.

The Mediterranean mussel, M. galloprovincialis, is a filter-feeding bivalve and lysozymes are believed to be involved in digestive processes [17] as well as in host defence [18]. In M. edulis, lysozyme has been found localised within granular hemocytes [19] and higher levels of activity have been detected in hemocytes compared with plasma [20] in both $M$. edulis and the carpet shell clam, Ruditapes decussatus [21]. However, mRNA transcripts of g-type lysozyme were most abundantly expressed in gills, hepatopancreas and gonad, but only weak expression was evident in hemocytes and mantle from the Zhikong scallop, Chlamys farreri [22]. In the Pacific oyster, Crassostrea gigas, lysozyme mRNA was expressed in all tissues except the adductor muscle and ISH (in situ hybridization) analyses revealed strong expression in basophilic cells from the digestive tubules [23]. Similarly, ISH located lysozyme gene expression in the mantle and gill cells of the eastern oyster, $C$. virginica, with significantly higher mRNA content in labial palps and mantles than in gills, digestive glands and hemocytes [14]. For a long time, hemocytes have been considered as primary mediators of anti infectious defence, yet no work has been done on the kinetics of lysozyme gene expression in response to various challenges.

The aim of the present report was to study the kinetics of expression of the M. galloprovincialis lysozyme gene in response to various stress factors: high temperature, low temperature, and bacterial injection. Quantification of lysozyme transcripts was done using Q-PCR (quantitative polymerase chain reaction) with $28 \mathrm{~S}$ ribosomal RNA as the house keeping gene. Visualisation of circulating hemocytes containing lysozyme mRNA was done by ISH and completed by histological observations of the posterior adductor muscles where injection took place.

\section{Materials and methods}

\subsection{Bacterial growth and mussel challenges}

Vibrio splendidus LGP32 is a Gram-negative marine bacterium isolated from juvenile oysters, C. gigas, during summer mortalities in 2001 [24], while $V$. anguillarum was from the Institut PasteurFrance (ATCC 19264). Both Vibrio species (50 $\mu$ l of overnight-cultured inoculum) were grown at $20^{\circ} \mathrm{C}$ in $10 \mathrm{ml}$ trypsin-casein-soya (TCS, AES Laboratoire, Bruz-France) for 4-6 $\mathrm{h}$ to ensure bacteria were in the exponential growth phase, then centrifuged for $10 \mathrm{~min}$ at $500 \mathrm{xg}$, and adjusted to $10^{8} \mathrm{CFU} / \mathrm{ml}$ with phosphate buffered solution isotonic to sea water (PBS-NaCl: $2 \mathrm{mM} \mathrm{KH}_{2} \mathrm{HPO}_{4}, 10 \mathrm{mM} \mathrm{Na} \mathrm{HPO}_{4}, 3$ $\mathrm{mM} \mathrm{KCl}, 600 \mathrm{mM} \mathrm{NaCl}$ in distilled water, $\mathrm{pH} 7.4$ ) according to $1 \mathrm{OD}_{600} \mathrm{~nm}=5 \times 10^{8} \mathrm{CFU} / \mathrm{ml}$. Micrococcus lysodeikticus from the Institut Pasteur-France (ATCC 4698 ) was grown at $37^{\circ} \mathrm{C}$ in Luria Broth (Sigma Chemical Co, St Louis MO-USA) until bacteria were in the exponential growth phase, then centrifuged $10 \mathrm{~min}$ at $500 \mathrm{xg}$, and adjusted at $10^{8} \mathrm{CFU} / \mathrm{ml}$ with PBS-NaCl according to $1 \mathrm{OD}_{600 \mathrm{~nm}}$ $=0.36 \times 10^{8} \mathrm{CFU} / \mathrm{ml}$. 
Adult M. galloprovincialis were purchased from the marine farm Les Compagnons de Maguelone (Palavas-France) in May-June 2006 and April 2007. They were maintained in the laboratory in oxygenated sea water at $20^{\circ} \mathrm{C}$ for $1-3$ days prior to experimentation. Four batches of 10 mussels each per sampling end-point were injected with $100 \mu \mathrm{l}\left(10^{7}\right.$ bacteria) into the posterior adductor muscle, through a hole created by light filing on the shells. After injection, mussels were returned to $20^{\circ} \mathrm{C}$ sea water. Control injections consisted of $100 \mu \mathrm{l}$ of PBS-NaCl. To test temperature stress, four batches of 10 mussels each per sampling end-point were subjected to 90 min immersion in sea water at either $30^{\circ} \mathrm{C}$ or $5^{\circ} \mathrm{C}$, with their subsequent return to $20^{\circ} \mathrm{C}$ sea water. Four batches of 10 untreated mussels each (referred to as untreated) were sampled simultaneously with each corresponding stress to minimize seasonal variations. Thus, the experiments involved a grand total of 2,160 mussels.

\subsection{Primers for lysozyme and $28 \mathrm{~S}$ ribosomal RNA}

Primers for lysozyme were designed from the $M$. galloprovincialis lysozyme mRNA (AF334665)[12]:

forward 5'-ATGTGGAATCTGAAGGACTTGT-3' (position 140-161) and

reverse 5'- CCAGTATCCAATGGTGTTAGGG-3' (position 486-507), giving an expected amplicon of 368 bp. Presence of a unique amplicon was checked by melting curve analysis (see 2.4) and gel electrophoresis on 2\% agarose in Tris-borate-EDTA buffer stained with ethidium bromide. Specificity has been confirmed by several complete sequencings performed by Millegen (Labège-France).

28S rRNA was used as the house-keeping gene according to Cellura et al [25] using the previously reported primer sequences:

forward, 5'-AAGCGGAGGAAAAGAAACTAAC-3' and

reverse, 5'-TTTACCTCTAAGCGGTTTCAC-3', giving an amplicon of 378 bp with a melting temperature of $90.17 \pm 0.04^{\circ} \mathrm{C}$, also sequenced for confirmation of identity.

\subsection{Hemolymph collection and cDNA synthesis}

Hemolymph (0.8 $\mathrm{ml}$ per mussel) was collected from the posterior adductor muscle at 1, 3, 6, 9, 12, 24, 48 and $72 \mathrm{~h}$ post-injection, or immediately after the temperature shock (time 0 ) and after 3,6 , $9,12,15,18$ and $24 \mathrm{~h}$ recovery at $20^{\circ} \mathrm{C}$. Hemolymph was extracted into a $1 \mathrm{ml}$ disposable syringe containing $0.2 \mathrm{ml}$ of the anti-coagulant modified Alsever's solution (MAS)[26]. Hemolymph from 10 mussels was pooled and the hemocytes pelleted by 15 min centrifugation at $800 \times g$ at $4^{\circ} \mathrm{C}$. Four pools of 10 mussels each, as replicates, were used for each sampling end-point. Total RNA was extracted with Trizol Reagent, according to the manufacturer's protocol (Invitrogen, Cergy Pontoise-France) and resuspended in $40 \mu \mathrm{l}$ Tris-EDTA buffer. First strand cDNAs were synthesized from RNA adjusted to 5 $\mu \mathrm{g}$ using hexaprimers (Invitrogen, Cergy Pontoise-France) and murine leukemia virus reverse transcriptase (Promega, Charbonnières-France), and purified with Wizard SV gel and PCR clean-up system (Promega, Charbonnières-France), then kept in nuclease-free water at $-20^{\circ} \mathrm{C}$ until use.

\subsection{Quantification of lysozyme transcripts by Q-PCR}

Q-PCR was performed on the 4 pools for each sampling end-point of similarly treated mussels using SYBR Green chemistry on a LightCycler 480384 well-plate (Roche Diagnostics, MeylanFrance). The Q-PCR mixture contained the following: $1 \mu \mathrm{l}$ first strand cDNA (10 ng), $0.75 \mu \mathrm{l}$ of each specific primer at a concentration of $25 \mu \mathrm{M}$, and $2.5 \mu \mathrm{l}$ of reaction mix (Roche Diagnostics, MeylanFrance) containing FastStart Taq DNA polymerase, reaction buffer 2x, dNTP mix, SYBR Green 1 dye and $\mathrm{MgCl}_{2}$. The PCR amplification programme started with initial Taq polymerase activation at $95^{\circ} \mathrm{C}$ for $10 \mathrm{~min}$, followed by 40 cycles at $95^{\circ} \mathrm{C}$ for $10 \mathrm{sec}, 65^{\circ} \mathrm{C}$ for $10 \mathrm{sec}$ and $72^{\circ} \mathrm{C}$ for $15 \mathrm{sec}$. Melting temperatures were measured by returning to $65^{\circ} \mathrm{C}$ for $30 \mathrm{sec}$ and gradual heating to $95^{\circ} \mathrm{C}$. Negative control reactions contained sterile water in place of the cDNA template and were included in each run to ensure the absence of contamination. Calibration curves were obtained using 10 -fold serial dilutions 
of lysozyme amplicon in $10 \mu \mathrm{g} / \mathrm{ml}$ sonicated salmon sperm DNA (Sigma-Aldrich Chimie, St QuentinFrance).

\subsection{Data analysis}

Crossing point values expressed in cycle numbers were measured according to a threshold position of 4.2 and converted into equivalent target amounts (ETA) by the LightCycler 480 software, using calibration curves. Lysozyme expression level was calculated from the ratio of ETA for lysozyme on ETA for 28S rRNA. Normalization of the ratios was calculated considering each ratio equal to 1 in untreated mussels and expressed as $\mathrm{x}$-fold the ratio for untreated mussels. Data were presented as the arithmetical mean of the four replicates \pm SEM. Normality of data distribution was assayed using the Shapiro-Wilk test available at http://cran.fr.r-project.org. To compare the data of individual endpoints with expression in untreated mussels, Student's t-test using t-Ease 2.8 ISI software was employed. Differences were considered significant when $\mathrm{p}<0.05$.

\subsection{Tissue sampling}

Hemocytes were collected in MAS and immediately fixed by dilution with 5 vol of $10 \%$ neutral buffered formalin (NBF: $46 \mathrm{mM} \mathrm{Na}_{2} \mathrm{HPO}_{4}, 30 \mathrm{mM} \mathrm{NaH}_{2} \mathrm{PO}_{4}, 3.7 \%$ formaldehyde in distilled water, $\mathrm{pH}$ 7). After centrifugation $\left(800 \mathrm{xg}, 15 \mathrm{~min}, 4^{\circ} \mathrm{C}\right)$, hemocytes were resuspended in $10 \mathrm{ml} 10 \% \mathrm{NBF}$ and incubated overnight at $4^{\circ} \mathrm{C}$. After washing in $70 \%$ ethanol by centrifugation $\left(800 \mathrm{xg}, 15 \mathrm{~min}, 4^{\circ} \mathrm{C}\right.$ ), hemocyte concentration was adjusted to $10^{7} \mathrm{cells} / \mathrm{ml}$ and one drop of $5 \mu \mathrm{l}$ was deposited on polylysine coated glass slides, air dried and kept at $4^{\circ} \mathrm{C}$. Total hemocyte numbers were determined in freshly collected hemolymph using Malassez' hemocytometer. Counts were done in duplicate for each of the 4 batches of untreated or experimentally treated mussels. Results are expressed as the arithmetic means \pm SEM.

The adductor muscle from each sampled mussel was carefully detached from surrounding tissues and shell, and immediately immersed in Davidson fixative (33\% of 95\% ethanol, $22 \%$ of $37 \%$ formaldehyde, $11 \%$ glacial acetic acid and $34 \%$ distilled water). After 2 days of fixation, muscles were kept in $70 \%$ ethanol. They were embedded in paraffin after dehydration in gradual, increased ethanol concentrations, sectioned at $2 \mu \mathrm{m}$ and laid on histological poly-lysine coated slides kept at room temperature.

\subsection{Probe synthesis and ISH (in situ hybridization) assay}

The lysozyme amplicon was synthesized by PCR using the same primers as for Q-PCR but using GoTaq DNA polymerase (Promega, Charbonnières-France). PCR conditions were: 2 min denaturation at $95^{\circ} \mathrm{C}$, followed by 30 cycles of $95^{\circ} \mathrm{C}$ for $40 \mathrm{sec}, 60^{\circ} \mathrm{C}$ for $30 \mathrm{sec}$ and $72^{\circ} \mathrm{C}$ for $40 \mathrm{sec}$, ended by final extension at $72{ }^{\circ} \mathrm{C}$ for $10 \mathrm{~min}$. After analysis on $2 \%$ agarose gel, the PCR amplicon was cloned using TOPO TA Cloning kit (Invitrogen, Cergy Pontoise-France) with PCR II-TOPO plasmid and the inserted sequence controlled by sequencing (Millegen, Labège-France). Antisense and sense digoxigenin (DIG) labeled riboprobes were synthesized from the plasmid using the DIG RNA Labeling Kit (SP6/T7) (Roche Diagnostics, Meylan-France).

Cells on slides were permeabilised with $3 \mu \mathrm{g} / \mathrm{ml}$ proteinase- $\mathrm{K}$ (Sigma-Aldrich Chimie, St Quentin-France) for $10 \mathrm{~min}$ at $37^{\circ} \mathrm{C}$ then fixed with $0.4 \%$ cold formaldehyde and rinsed 5 min with $2 \mathrm{X}$ sodium chloride/sodium citrate buffer (2X SSC: $150 \mathrm{mM} \mathrm{NaCl}, 15 \mathrm{mM}$ sodium citrate in distilled water, $\mathrm{pH}$ 7). Histological sections of muscles were heated at $65^{\circ} \mathrm{C}$ during $45 \mathrm{~min}$, gradually hydrated in gradual, decreased ethanol concentrations, then permeabilised with $6 \mu \mathrm{g} / \mathrm{ml}$ proteinase- $\mathrm{K}$ for $10 \mathrm{~min}$ at $37^{\circ} \mathrm{C}$.

Lysozyme riboprobes $(50 \mathrm{ng} / \mathrm{ml})$ were denatured for $15 \mathrm{~min}$ at $95^{\circ} \mathrm{C}$, and hybridisation was performed overnight at $37^{\circ} \mathrm{C}$ in a humid chamber with $50 \%$ formamide, $1 \mathrm{X}$ Denhard's, $5 \%$ dextran sulphate and $0.5 \mathrm{mg} / \mathrm{ml}$ salmon sperm DNA in 4X SSC. Unbound riboprobes were removed by washing twice (30 min, room temperature) with $2 \mathrm{X} \mathrm{SSC}$, then twice $\left(5 \mathrm{~min}, 37^{\circ} \mathrm{C}\right.$ ) with $1 \mathrm{X} \mathrm{SSC}$ and twice $\left(5 \mathrm{~min}, 37^{\circ} \mathrm{C}\right)$ with $0.5 \mathrm{XSSC}$. Cells and muscle sections were equilibrated for 5 min in Buffer 1 
$(1 \mathrm{M}$ Tris- $\mathrm{HCl}, \mathrm{pH} 7.5,1.5 \mathrm{M} \mathrm{NaCl})$ then incubated $\left(15 \mathrm{~min}, 37^{\circ} \mathrm{C}\right)$ with $500 \mu \mathrm{l}$ of $0.5 \%$ blocking reagent (Roche Diagnostics, Meylan-France) in Buffer 1. Cells and muscle sections were then incubated with sheep anti-DIG Fab fragments (Roche Diagnostics, Meylan-France) conjugated to alkaline phosphatase $\left(30 \mathrm{~min}, 37^{\circ} \mathrm{C}\right)$, then washed twice for $5 \mathrm{~min}$ in Buffer 1 . The colorimetric reaction occurred during $3 \mathrm{~h}$ incubation in a freshly prepared solution of nitroblue tetrazolium and 5-bromo-4chloro-3-indolylphosphate (NBT/BCIP) (Promega, Charbonnières-France) diluted in Buffer $3(100 \mathrm{mM}$ Tris- $\mathrm{HCl}, \mathrm{pH} 9.5,100 \mathrm{mM} \mathrm{NaCl}, 50 \mathrm{mM} \mathrm{MgCl}_{2}, 1 \%$ PolyVinyle Alcohol). The slides were subsequently rinsed with Buffer 4 (100 mM Tris- $\mathrm{HCl}, \mathrm{pH}$ 8, $10 \mathrm{mM}$ EDTA).

To enhance the contrast, counter-staining was done with 0.5\% Bismarck Brown $Y$ solution (Sigma-Aldrich Chimie, St Quentin-France). After being dehydrated in 95 and 100\% ethanol and treated three times with non-toxic LMR-SOL solvent (Labo-Moderne, Paris-France), hemocytes and muscle sections were mounted with a cover-slip using the permanent mounting medium Histalaque (Labo-Moderne, Paris-France). Observations were made with a photonic microscope Leica DMR (Leica Microsystems, Wetzlar-Germany) equipped with a Leica DC200 camera.

\section{Results}

\subsection{Specificity of lysozyme amplicon}

The sequences of both mRNAs from $M$. galloprovincialis (AF334665) and the one deduced from $M$. edulis gene (AF334662) present a high degree of identity with only 43 nucleotides different out of 531, representing $8 \%$. In addition, such differences were homogeneously spread all along the cDNA sequences with only a single substitution at each difference. The exception was 3 consecutive bases located in position 417-419. The only cDNA amplicon obtained in Q-PCR was of 368 bp (Fig. 1) and corresponded to the expected size deduced from the reported cDNA sequence. Amplicons from several Q-PCR were analyzed for DNA melting temperature revealing only one symmetrical peak at $82.88 \pm 0.08^{\circ} \mathrm{C}$ (Fig. 1). Definite confirmation of the primer specificity was obtained from several sequencings, showing total nucleotide sequence alignment with the expected $M$. galloprovincialis cDNA sequence reported in databank (AF334665) as belonging to i (invertebrate) type of lysozyme [12]. In addition, the nucleotide sequence of the M. galloprovincialis amplicon possessed only $45 \%$ and 51\% identity with type-c lysozyme (Marsupenaeus japonicus, AB080238) and type-g lysozyme (Chlamys farreri, DF718947) including 9 to 15 gaps to enforce alignment, respectively.

\subsection{Relative concentrations of $28 \mathrm{~S}$ rRNA transcript}

The expression of $28 \mathrm{~S}$ rRNA gene was measured by Q-PCR in all the cDNA samples collected from each time point. Samples collected from untreated mussels on the day of the corresponding challenge did not possess identical 28S rRNA content. ETA ranged from $3.69 \times 10^{4} \pm$ $0.39 \times 10^{4}$ to $7.15 \times 10^{4} \pm 0.56 \times 10^{4}$ according to the various batches of mussels, with no statistically significant differences (not shown). ETA was not stable throughout the duration of the various challenges but corresponded closely to the concentration in untreated animals (fold change from 0.77 to 1.19). None of the stress factors had a significant effect on $28 \mathrm{~S}$ rRNA expression, confirming that the use of the 28S rRNA gene to normalize levels of gene expression in mussels is appropriate.

\subsection{Effect of bacterial and PBS- $\mathrm{NaCl}$ injection on hemocyte lysozyme mRNA expression}

Injection of $V$. splendidus LGP32 resulted in a general decrease in lysozyme mRNA levels as shown in Fig. 2. The maximum decrease of $-3.47 \pm 0.11$ fold the ratio in untreated mussels $(p=0.00001)$ was observed $6 \mathrm{~h}$ after injection. Injections of both $V$. anguillarum and M. lysodeikticus resulted in an increase in lysozyme mRNA with a maximum observed after $48 \mathrm{~h}$ for $V$. anguillarum $(4.15 \pm 0.71 ; p=0.004)$ and $72 \mathrm{~h}$ for $M$. Iysodeikticus $(5.78 \pm 0.87 ; p=0.005)$. Only a transient, 
statistically significant decrease was observed after $3 \mathrm{~h}$ for $V$. anguillarum $(-2.10 \pm 0.17 ; p=0.002)$, whereas small, but statistically significant increases, were recorded with PBS- $\mathrm{NaCl}$ injection at $9 \mathrm{~h}$ $(1.67 \pm 0.14 ; p=0.033)$ and $48 \mathrm{~h}(1.61 \pm 0.07 ; p=0.19)$.

\subsection{Effect of heat shock and cold stress in hemocyte lysozyme mRNA expression}

Limited increases in lysozyme mRNA levels were obtained after heat shock, with a maximum (but not significant value) of 2.60 fold the ratio in untreated mussels after $12 \mathrm{~h}$ of recovery (Fig. 3). The only statistically significant value was recorded after $3 \mathrm{~h}$ of recovery $(2.16 \pm 0.08 ; \mathrm{p}=0.002)$. In contrast, cold stress resulted in a general decrease in the quantity of lysozyme mRNA, being minimal after $15 \mathrm{~h}$ of recovery $(-3.84 \pm 0.08 ; p=0.022)$, the only significant difference from untreated mussels.

\subsection{Lysozyme expression in circulating hemocytes}

ISH with antisense lysozyme riboprobe has been performed on hemocytes collected from all the sampling end-points of all the injected mussels, plus the untreated. In untreated mussels, labelling of lysozyme mRNA was observed only in some granulocytes (Fig. 4). The small hemocytes referred to as hyalinocytes appeared unstained. Six hours after injection of $V$. splendidus LGP32, the total number of circulating hemocytes was significantly lower than in untreated $\left(1.42 \times 10^{6} \pm 0.14 \times 10^{6}\right.$ versus $2.37 \times 10^{6} \pm 0.22 \times 10^{6}, p=0.005$; not shown) and very few hemocytes were labelled (Fig. 4). In addition, the labelling was restricted to small cells, the large cells, mainly granulocytes were no longer stained. Forty eight hours after injection of $V$. anguillarum or M. lysodeikticus, numerous, but not all, small and large hemocytes were stained by the lysozyme riboprobe. At that time, total numbers of circulating hemocytes did not vary significantly from untreated, ranging from $2.50 \times 10^{6} \pm 0.15 \times 10^{6}$ in the corresponding untreated to $3.00 \times 10^{6} \pm 0.23 \times 10^{6}(\mathrm{p}=0.094)$ after injection of $V$. anguillarum and from $2.27 \times 10^{6} \pm 0.21 \times 10^{6}$ in the corresponding untreated to $2.90 \times 10^{6} \pm 0.19 \times 10^{6}(p=0.0502)$ after injection of $M$. lysodeikticus. The specificity of hybridization was controlled by incubation with sense riboprobe, resulting in the absence of blue coloration.

\subsection{Accumulation of hemocytes within muscle}

Histological sections of adductor muscle from untreated mussels revealed the presence of narrow sinuses between the muscular fibres. The lumen of the sinuses contained few hemocytes including some labelled granulocytes, and liquid hemolymph was observed as open spaces after histological treatments (Fig. 5). Six hours after injection of V. splendidus LGP32, the sinuses were enlarged and the lumen was almost completely filled with numerous aggregated hemocytes, the cytoplasm of which being labelled. In muscles injected $48 \mathrm{~h}$ before with $V$. anguillarum, the size of the sinuses were similar to those of untreated mussels, but the lumen was completely filled with unstained aggregated hemocytes. In contrast, injection of $M$. lysodeikticus resulted in sinuses resembling the ones of untreated mussels, with open spaces, few hemocytes and rare labelling.

\section{Discussion}

For a long time, mollusc hemocytes have been reported to be responsible for bactericidal activity mediated by numerous toxic compounds, such as lysozyme [17], superoxide [27], lysosomal enzymes [21], nitric oxide [28], phenoloxidase [29] and antimicrobial peptides [30, 31]. In addition, signal transduction pathways in $M$. galloprovincialis [32] and Crassostrea gigas [33, 34] have been identified. Few studies, however, concentrated on the in vivo regulation of the immune genes, with those to date reporting that expression of immune-related genes have been modulated by physical stress, bacterial challenges or exposure to poly aromatic hydrocarbons [35-39]. In the present study, the kinetics of expression of the $M$. galloprovincialis lysozyme gene in response to different in vivo challenges was established. According to single melting curve of PCR amplicon, to total nucleotide 
sequence identity with type-i lysozyme, and to low nucleotide sequence identities with type-c and type$\mathrm{g}$ lysozymes, we considered both mRNA quantification and ISH referred to the unique type-i lysozyme of $M$. galloprovincialis.

According to previous reports [25,39], we decided to maintain the quantification of $28 \mathrm{~S}$ rRNA mRNA as representative of house keeping gene expression to be used in Q-PCR. However, the expression of 28S rRNA was not constant in untreated mussels collected during different weeks, at the time of the corresponding challenge. This observation confirmed the effect of the season on mussel physiology $[29,40]$ and underlines the absolute necessity to perform the challenges during the same season when comparisons are required. In addition, no one gene expression is strictly unaffected by experimental treatments. In our challenges, the quantities of $28 \mathrm{~S}$ rRNA transcripts varied. No significant down regulation was observed, and only the injection of $V$. splendidus LGP32 was able to significantly up-regulate this gene. Although mathematically significantly different $(p<0.05)$, the up-regulations were lower than 1.21 fold the expression in untreated mussels. Such slight variations may represent normal modulations of expression in a living organism. Consequently, and in agreement with the 4 to 10 fold up-regulation previously observed for antimicrobial peptides (AMPs) and HSP70 [25, 39], we decided that variations lower than 4 fold the one observed in untreated mussels will not be considered to reflect a biological response to the challenge.

Regarding lysozyme gene expression with this limitation, only up-regulations were observed, and only following $V$. anguillarum or M. lysodeikticus injection. Both were at the later end-points of 2 to 3 days post-injection, revealing the delay in the triggering of the lysozyme gene expression. Curiously, $M$. lysodeikticus was the only bacterium not capable of up-regulating the gene expression of the 3 AMPs and of HSP70 [39]. Only V. splendidus LGP32 has been suspected to induce mortality in bivalves [24], but neither lysozyme (this report) nor mytilin, myticin and HSP70 [39] gene expressions were up-regulated after injection of $V$. splendidus LGP32. One can hypothesize relationships between the nature/structure of the injected bacteria and the immune-related gene response. Neither heat shock nor cold stress resulted in significant modulation of lysozyme gene expression. A much earlier study reported both individual and seasonal variability of hemolymph lysozyme activity in oysters [41]. More recently, heat shock was demonstrated to cause rapid induction of HSP70 and AMP myticin gene expression in M. galloprovincialis [39]. Subsequently, in the present study, lysozyme gene expression in hemocytes appeared variable, but not influenced by temperature shock.

The different cell types found in the hemolymph of mussels were reported in the 1990s. The general assertion was that 2 cell categories existed in $M$. edulis: (i) hyalinocytes and (ii) granulocytes which might be subdivided according to granule size [42]. Staining capacities resulted also in 2 cell types: (i) basophils (about $40 \%$ of the total hemocytes) with a large majority of hyalinocytes and (ii) eosinophils (about 60\%) with small and large granules [43, 44]. Also 2 cell types were described in $M$. galloprovincialis, (i) hyalinocytes with characteristics of undifferentiated cells, and (ii) granulocytes being acidophils, basophils or both [45]. Both phenoloxidase/peroxidase activities and lysozyme were found associated with the granules of eosinophils $[19,29]$. Despite the fact that monoclonal antibodies revealed 3 cell types [46], we decided to consider the two easily distinguishable categories, hyalinocytes and granulocytes. In the present report, lysozyme mRNA has been detected by ISH within the granulocytes in untreated mussels, however, injection of bacteria dramatically modified that profile. A few hours after injection of $V$. splendidus LGP32, the number of circulating hemocytes was dramatically reduced. The decrease in lysozyme mRNA transcript number revealed by Q-PCR was not due to the collection of less hemocytes, as cDNA concentrations had been adjusted to $10 \mathrm{ng}$ in all the samples. ISH confirmed that few of the circulating hemocytes contained lysozyme mRNA, whereas histological observation revealed numerous hemocytes aggregated within the enlarged muscle sinuses and expressing the lysozyme gene. The accumulation of hemocytes containing mytilin has been also observed after bacterial challenge [47]. Presumably, this neutralizes localized infection, yet accumulation of hemocytes at the injection site resulted at least temporarily in lowering the number of circulating immune cells, consequently reducing the capacity to counter infection in another location.

The response to $V$. anguillarum was totally different, with no difference in the number of circulating hemocytes but some accumulation in the muscle sinuses. The numerous hemocytes containing lysozyme observed in circulation, from both large and small cells, may explain the upregulation detected by Q-PCR. Similarly, $M$. Iysodeikticus challenge resulted both in up-regulation of the lysozyme gene expression, and observations of numerous hemocytes containing lysozyme in circulation. No obvious accumulation, however, was observed in the muscle sinuses and the number of circulating hemocytes was not significantly different to those from untreated animals, revealing different responses of the hemocytes according to the nature of the injected bacteria. 
Other studies using clams have shown that defence-related factors were modulated in hemolymph in response to $V$. tapetis injection. For instance, lysozyme activity of cell-free hemolymph significantly increased 24-72 h post-challenge in Ruditapes philippinarum [48], as we observed in $M$. galloprovincialis challenged with both $V$. anguillarum and $M$. Iysodeikticus. In contrast, no correlation was found between lysozyme activity from cell-free hemolymph and infection by the protozoan, Bonamia ostreae in the flat oyster, Ostrea edulis [49]. On the contrary to observations in mussels, lysozyme of the shrimp, Litopenaeus vannamei, is expressed in nearly all the circulating hemocytes [50]. Meanwhile, the shrimp response to an injection of $V$. campbellii resembled the one of $M$. galloprovincialis after injection of $V$. splendidus LGP32: i.e. decrease in lysozyme mRNA within the first hours following injection, with simultaneous recruitment and accumulation of hemocytes at the injection site.

In summary, based on quantification of lysozyme gene expression, total hemocyte counts, observation of hemocytes containing lysozyme mRNA and hemocyte accumulation at the site of injection, it appeared that hemocyte populations reacted differently according to the nature of the stress. Hemocytes were able to differentiate amongst bacterial species, even between two Vibrio species, whereas physical stress or PBS-NaCl injection did not strongly modulate the expression of the lysozyme gene. Further studies must address the behaviour of the other known immune molecules in order to obtain a complete overview of an innate immune response.

\section{Acknowledgments}

Authors thank Eva Blondeau-Bidet for performing histological sectioning. We thank Marie-Christine Guérin and Joel Martin (Université de Montpellier 2-France) for technical assistance with Q-PCR and Elisabeth A. Dyrynda for improving the language. Experiments were partially supported by the EU program IMAQUANIM (FOOD-CT-2005-007103), the Région Languedoc-Roussillon (Montpellier, France) and the INTERLINK programme from the Ministero dell'Università e della Ricerca-Italy and the Università degli studi di Palermo-Italy.

\section{References}

[1] Nilsen IW, Overbo K, Sandsdalen E, Sandaker E, Sletten K, Myrnes B. Protein purification and gene isolation of chlamysin, a cold-active lysozyme-like enzyme with antibacterial activity. FEBS Lett 1999;464:153-8.

[2] Xue QG, Schey KL, Volety AK, Chu FL, La Peyre JF. Purification and characterization of lysozyme from plasma of the eastern oyster (Crassostrea virginica). Comp Biochem Physiol B Biochem Mol Biol 2004;139:11-25.

[3] de-la-Re-Vega E, Garcia-Galaz A, Diaz-Cinco ME, Sotelo-Mundo RR. White shrimp (Litopenaeus vannamei) recombinant lysozyme has antibacterial activity against Gram negative bacteria: Vibrio alginolyticus, Vibrio parahemolyticus and Vibrio cholerae. Fish Shellfish Immunol 2006;20:405-8.

[4] Hikima S, Hikima J, Rojtinnakorn J, Hirono I, Aoki T. Characterization and function of kuruma shrimp lysozyme possessing lytic activity against Vibrio species. Gene 2003;316:187-95.

[5] Bierman J, MacInnis AJ, Lobstein OE. Effects of lysozyme on Trypanosoma lewisi. Ann Clin Lab Sci 1979;9:381-6.

[6] Samaranayake YH, Samaranayake LP, Wu PC, So M. The antifungal effect of lactoferrin and lysozyme on Candida krusei and Candida albicans. Apmis 1997;105:875-83.

[7] Ibrahim HR, Thomas U, Pellegrini A. A helix-loop-helix peptide at the upper lip of the active site cleft of lysozyme confers potent antimicrobial activity with membrane permeabilization action. J Biol Chem 2001;276:43767-74.

[8] Prager EM, Jolles P. Animal lysozymes c and g: an overview. Exs 1996;75:9-31.

[9] Ito Y, Yoshikawa A, Hotani T, Fukuda S, Sugimura K, Imoto T. Amino acid sequences of lysozymes newly purified from invertebrates imply wide distribution of a novel class in the lysozyme family. Eur J Biochem 1999;259:456-61. 
[10] Olsen OM, Nilsen IW, Sletten K, Myrnes B. Multiple invertebrate lysozymes in blue mussel (Mytilus edulis). Comp Biochem Physiol B Biochem Mol Biol 2003;136:107-15.

[11] Jolles J, Fiala-Medioni $A$, Jolles $P$. The ruminant digestion model using bacteria already employed early in evolution by symbiotic molluscs. J Mol Evol 1996;43:523-7.

[12] Bachali S, Jager M, Hassanin A, Schoentgen F, Jolles P, Fiala-Medioni A, et al. Phylogenetic analysis of invertebrate lysozymes and the evolution of lysozyme function. J Mol Evol 2002;54:652-64.

[13] Xue QG, Itoh N, Schey KL, Li YL, Cooper RK, La Peyre JF. A new lysozyme from the eastern oyster (Crassostrea virginica) indicates adaptive evolution of i-type lysozymes. Cell Mol Life Sci 2007;64:82-95.

[14] Itoh N, Xue Q, Li Y, Cooper RK, La Peyre JF. cDNA cloning and tissue expression of plasma lysozyme in the eastern oyster, Crassostrea virginica. Fish Shellfish Immunol 2007;23:957-68.

[15] Itoh N, Takahashi KG. cDNA cloning and in situ hybridization of a novel lysozyme in the Pacific oyster, Crassostrea gigas. Comp Biochem Physiol B Biochem Mol Biol 2007;148:160-6.

[16] Nilsen IW, Myrnes B. The gene of chlamysin, a marine invertebrate-type lysozyme, is organized similar to vertebrate but different from invertebrate chicken-type lysozyme genes. Gene 2001;269:27-32.

[17] McHenery JG, Birkbeck TH, Allen JA. The occurrence of lysozyme in marine bivalves. . Comparative Biochemistry and Physiology 1979;B 63:25-8.

[18] Cheng TC. Triggering of immunologic defense mechanisms of molluscan shellfish by biotic and abiotic challenge and its applications. Marine Technology Society Journal 1983;17:18-25.

[19] Pipe RK. Hydrolytic enzymes associated with the granular haemocytes of the marine mussel Mytilus edulis. Histochem J 1990;22:595-603.

[20] Carballal MJ, Lopez C, Azevedo C, Villalba A. Enzymes Involved in Defense Functions of Hemocytes of Mussel Mytilus galloprovincialis. J Invertebr Pathol 1997;70:96-105.

[21] Lopez C, Carballal MJ, Azevedo C, Villalba A. Enzyme characterisation of the circulating hemocytes of the carpet shell clam, Ruditapes decussatus (Mollusca: bivalvia). Fish Shellfish Immunol 1997;7:595-608.

[22] Zhao J, Song L, Li C, Zou H, Ni D, Wang W, et al. Molecular cloning of an invertebrate goosetype lysozyme gene from Chlamys farreri, and lytic activity of the recombinant protein. Mol Immunol 2007;44:1198-208.

[23] Matsumoto T, Nakamura AM, Takahashi KG. Cloning of cDNAs and hybridization analysis of lysozymes from two oyster species, Crassostrea gigas and Ostrea edulis. Comp Biochem Physiol B Biochem Mol Biol 2006;145:325-30.

[24] Gay M, Berthe FC, Le Roux F. Screening of Vibrio isolates to develop an experimental infection model in the Pacific oyster Crassostrea gigas. Dis Aquat Organ 2004;59:49-56.

[25] Cellura C, Toubiana M, Parrinello N, Roch P. HSP70 gene expression in Mytilus galloprovincialis hemocytes is triggered by moderate heat shock and Vibrio anguillarum, but not by V. splendidus or Micrococcus lysodeikticus. Dev Comp Immunol 2006;30:984-97.

[26] Torreilles J, Guérin M-C, Roch P. Modified Alsever's solution is not a good medium for reactive oxygen metabolite study in bivalves. Fish Shellfish Immunol 1999;8:65-9.

[27] Nakamura M, Mori K, Inooka S, Nomura T. In vitro production of hydrogen peroxide by the amoebocytes of the scallop, Patinopecten yessoensis (Jay). Dev Comp Immunol 1985;9:407-17.

[28] Ottaviani E, Paeman LR, Cadet P, Stefano GB. Evidence for nitric oxide production and utilization as a bacteriocidal agent by invertebrate immunocytes. Eur J Pharmacol 1993;248:319-24.

[29] Coles JA, Pipe RK. Phenoloxidase activity in the hemolymph and hemocytes of the marine mussel, Mytilus edulis. Fish Shellfish Immunol 1994;4:337-52.

[30] Charlet M, Chernysh S, Philippe H, Hetru C, Hoffmann JA, Bulet P. Innate immunity. Isolation of several cysteine-rich antimicrobial peptides from the blood of a mollusc, Mytilus edulis. J Biol Chem 1996;271:21808-13.

[31] Hubert $F$, Noel $T$, Roch P. A member of the arthropod defensin family from edible Mediterranean mussels (Mytilus galloprovincialis). Eur J Biochem 1996;240:302-6.

[32] Canesi L, Betti M, Ciacci C, Scarpato A, Citterio B, Pruzzo C, et al. Signaling pathways involved in the physiological response of mussel hemocytes to bacterial challenge: the role of stressactivated p38 MAP kinases. Dev Comp Immunol 2002;26:325-34.

[33] Barreau-Roumiguiere C, Montagnani C, Escoubas JM. Characterization of a Tal/SCL-like transcription factor in the pacific oyster Crassostrea gigas. Dev Comp Immunol 2003;27:793-800.

[34] Montagnani C, Kappler C, Reichhart JM, Escoubas JM. Cg-Rel, the first Rel/NF-kappaB homolog characterized in a mollusk, the Pacific oyster Crassostrea gigas. FEBS Lett 2004;561:75-82. 
[35] Snyder MJ, Girvetz E, Mulder EP. Induction of marine mollusc stress proteins by chemical or physical stress. Arch Environ Contam Toxicol 2001;41:22-9.

[36] Piano A, Valbonesi P, Fabbri E. Expression of cytoprotective proteins, heat shock protein 70 and metallothioneins, in tissues of Ostrea edulis exposed to heat and heavy metals. Cell Stress Chaperones 2004;9:134-42.

[37] Franzellitti S, Fabbri E. Differential HSP70 gene expression in the Mediterranean mussel exposed to various stressors. Biochem Biophys Res Commun 2005;336:1157-63.

[38] Tanguy A, Boutet I, Laroche J, Moraga D. Molecular identification and expression study of differentially regulated genes in the Pacific oyster Crassostrea gigas in response to pesticide exposure. Febs J 2005;272:390-403.

[39] Cellura C, Toubiana M, Parrinello N, Roch P. Specific expression of antimicrobial peptide and HSP70 genes in response to heat-shock and several bacterial challenges in mussels. Fish Shellfish Immunol 2007;22:340-50.

[40] Santarem MM, Robledo JAF, Figueras A. Seasonal changes in hemocytes and serum defense factors in the blue mussel Mytilus galloprovincialis. Dis Aquat Organ 1998;18:217-22.

[41] Chu F-LE, Peyre JFL. Effect of environmental factors and parasitism on hemolymph lysozyme and protein of American oysters (Crassostrea virginica). Journal Invertebrate Pathology 1989;54:22432.

[42] Pipe RK. Differential binding of lectins to haemocytes of the mussel, Mytilus edulis. Cell Tissue Res 1990;261:261-8.

[43] Pipe RK, Farley SR, Coles JA. The separation and characterisation of haemocytes from the mussel Mytilus edulis. Cell Tissue Res 1997;289:537-45.

[44] Dyrynda EA, Law RJ, Dyrynda PEJ, Kelly CA, Pipe RK, Graham KL, et al. Modulations in cellmediated immunity of Mytilus edulis following the "Sea Empress" oil spill. J mar biol Ass UK 1997;77:281-4.

[45] Carballal MJ, Lopez MC, Azevedo C, Villalba A. Hemolymph cell types of the mussel, Mytilus galloprovincialis. Dis Aquat Organ 1997;29:127-35.

[46] Dyrynda EA, Pipe RK, Ratcliffe NA. Sub-populations of haemocytes in the adult and developing marine mussel, Mytilus edulis, identified by use of monoclonal antibodies. Cell Tissue Res 1997;289:527-36.

[47] Mitta G, Vandenbulcke F, Hubert F, Salzet M, Roch P. Involvement of mytilins in mussel antimicrobial defense. J Biol Chem 2000;275:12954-62.

[48] Allam B, Paillard C, Auffret M, Ford SE. Effects of the pathogenic Vibrio tapetis on defence factors of susceptible and non-susceptible bivalve species: II. Cellular and biochemical changes following in vivo challenge. Fish Shellfish Immunol 2006;20:384-97.

[49] Cronin MA, Culloty SC, Mulcahy MF. Lysozyme activity and protein concentration in the haemolymph of the flat oyster Ostrea edulis (L.). Fish Shellfish Immunol 2001;11:611-22.

[50] Burge EJ, Madigan DJ, Burnett LE, Burnett KG. Lysozyme gene expression by hemocytes of Pacific white shrimp, Litopenaeus vannamei, after injection with Vibrio. Fish Shellfish Immunol 2007;22:327-39. 


\section{Figures}

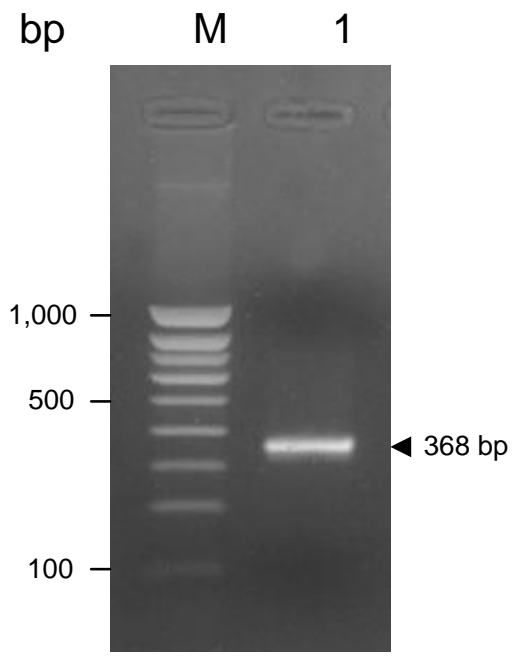

Gel electrophoresis

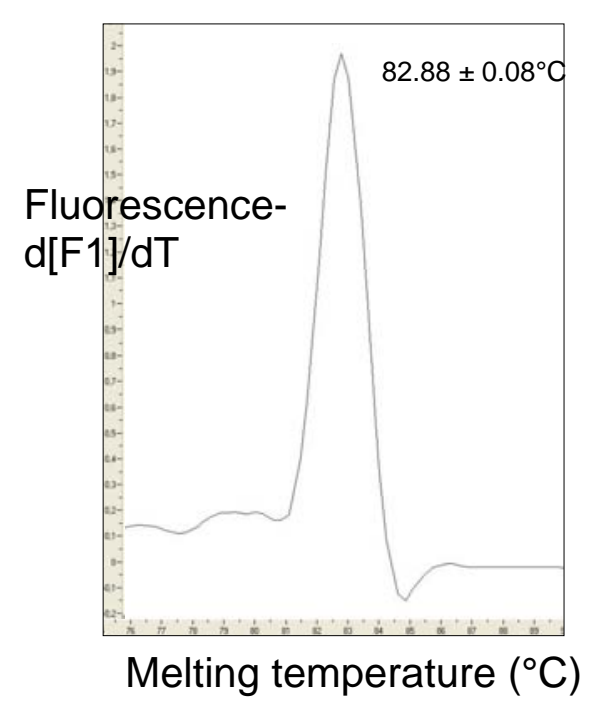

Figure 1

Figure 1 - Gel electrophoresis migration and melting curve of Q-PCR lysozyme amplicon revealing the presence of a unique product of amplification at $368 \mathrm{bp}$ and $82.88 \pm 0.08^{\circ} \mathrm{C}$. M: DNA molecular weight marker. 1: Q-PCR amplicon. 


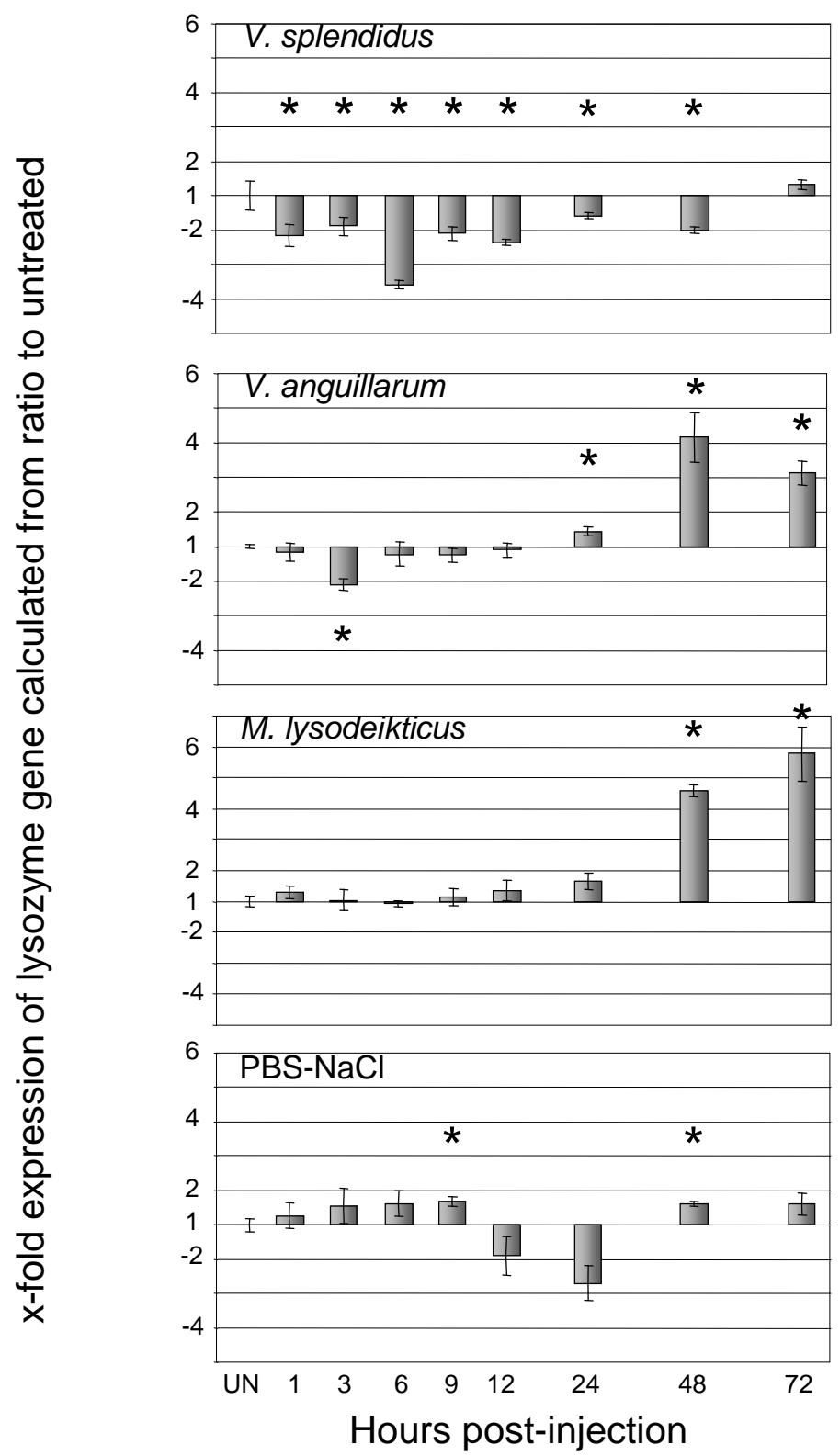

\section{Figure 2}

Figure 2 - Kinetics of expression level of lysozyme gene following injection of Vibrio splendidus LGP32, V. anguillarum, M. Iysodeikticus or PBS-NaCl. Values were inferred from 4 experiments performed in duplicate and plotted as mean \pm SEM (bar). *: values statistically significantly different from untreated (UN) with $p<0.05$. 

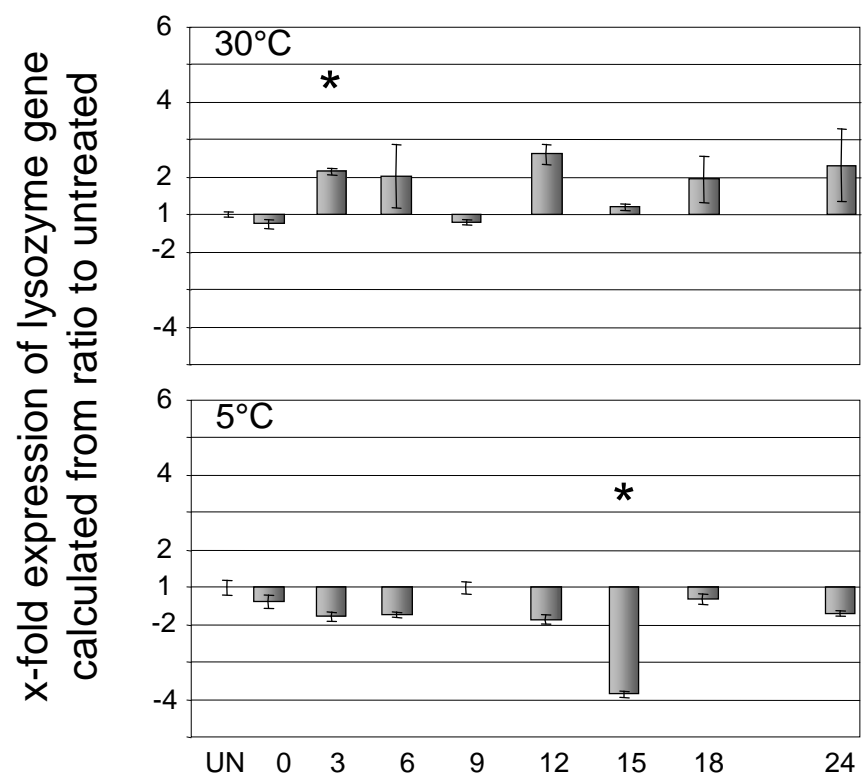

Hours post-temperature stress

\section{Figure 3}

Figure 3 - Kinetics of expression level of lysozyme gene after temperature stress at $30^{\circ} \mathrm{C}$ and $5^{\circ} \mathrm{C}$. Values were inferred from 4 experiments performed in duplicate and plotted as mean \pm SEM (bar). *: values statistically significantly different from untreated (UN) with $p<0.05$. 

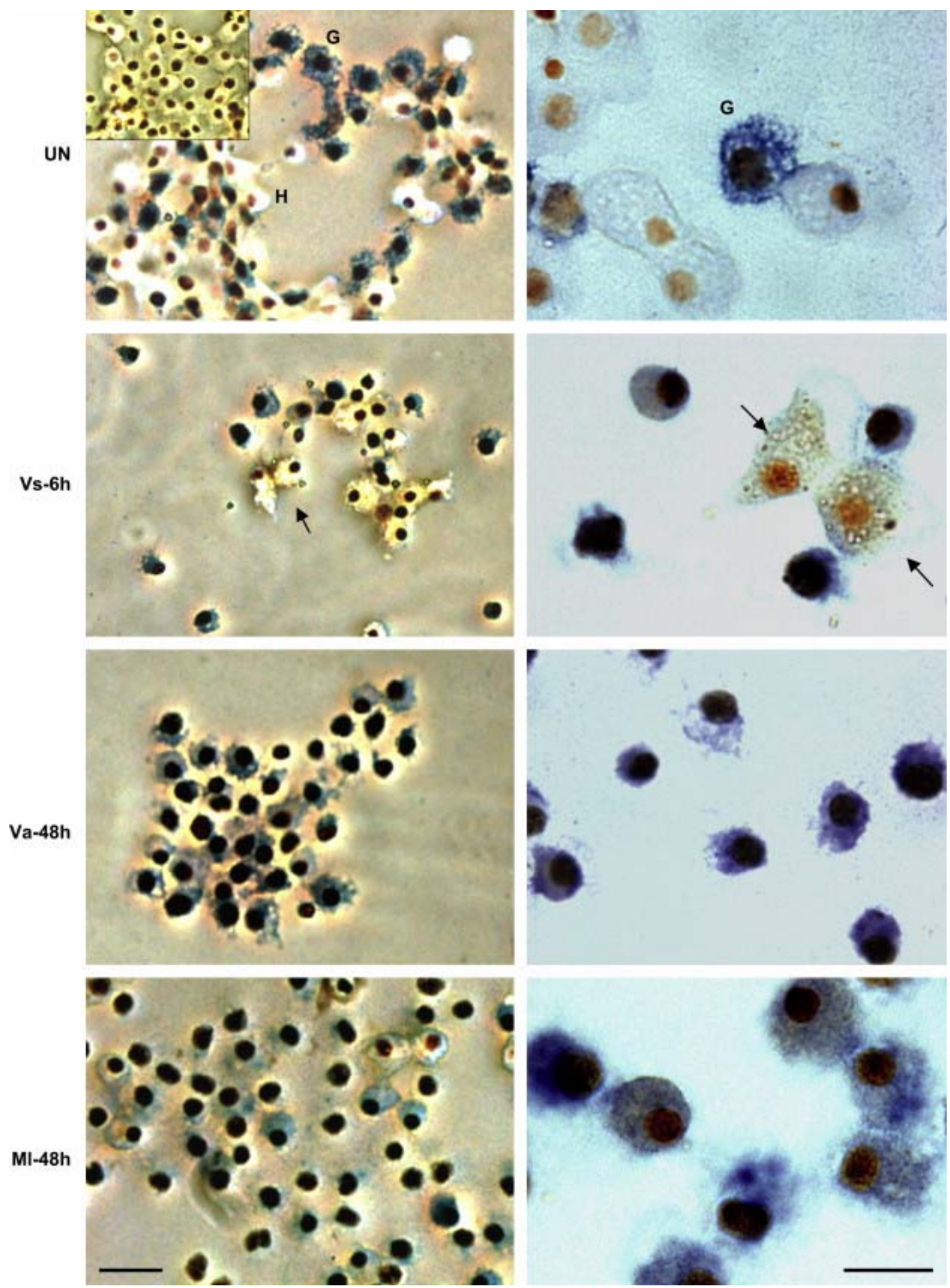

Figure 4 - Optical microscopy observations of ISH on circulating hemocytes from untreated (UN) and bacteria-injected mussels revealing lysozyme gene expression in blue. Counter staining of nuclei was with Bismarck brown. Vs-6h: Vibrio splendidus LGP32 $6 \mathrm{~h}$ post-injection; Va-48h: V. anguillarum $48 \mathrm{~h}$ post-injection; Ml-48: Micrococcus lysodeikticus $48 \mathrm{~h}$ post-injection. G: granulocytes expressing lysozyme gene; $\mathrm{H}$ : hyalinocytes not expressing lysozyme gene. Upper left window in UN corresponded to hybridization with sense lysozyme probe. Note the absence of blue coloration in granulocytes from Vs-6h (arrows), the disappearance of granulocytes and the blue coloration of all the small hemocytes from Va-48h, and the mixed population of blue granulocytes and small hemocytes from Ml-48h. Magnification bars: $50 \mu \mathrm{m}$ (left column) and $20 \mu \mathrm{m}$ (right column). 


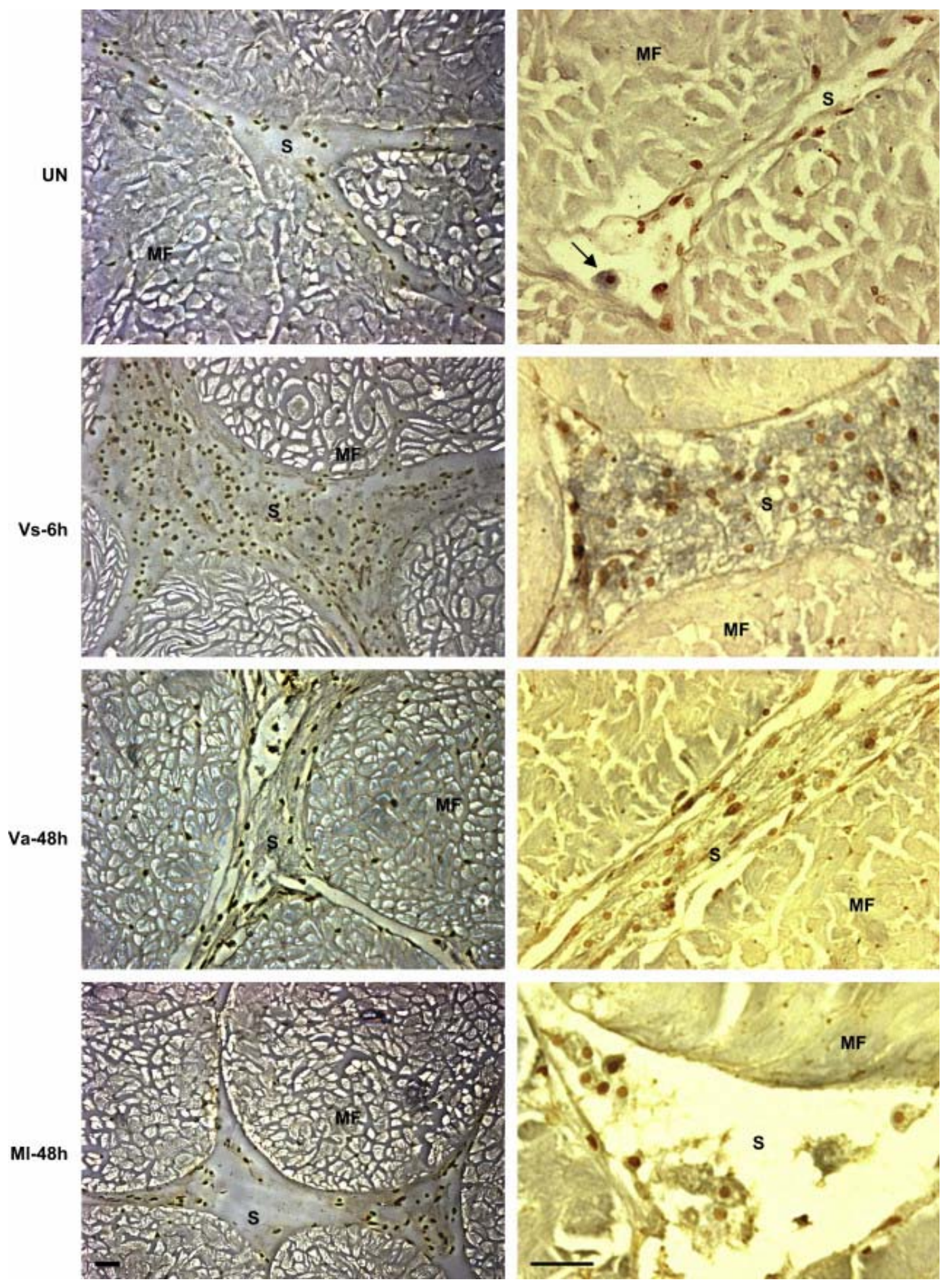

Figure 5 - Optical microscopy observations of ISH on posterior adductor muscle from untreated (UN) and bacteria-injected mussels revealing lysozyme gene expression. Counter staining of nuclei was with Bismarck brown. Vs-6h: Vibrio splendidus LGP32 $6 \mathrm{~h}$ post-injection; Va-48h: V. anguillarum $48 \mathrm{~h}$ post-injection; Ml-48: Micrococcus lysodeikticus $48 \mathrm{~h}$ post-injection. MF: muscle fibers; S: sinus. Note the open clear sinus in UN containing one blue stained granulocyte (arrow), the enlarged sinus containing aggregated blue stained hemocytes from Vs-6h, the accumulation of unstained aggregated hemocytes within narrow sinus from $\mathrm{Va}-48 \mathrm{~h}$, and the open sinus containing few free hemocytes from Ml-48h. Magnification bars: $50 \mu \mathrm{m}$. 